Article

\title{
Antibacterial Properties of Visible-Light-Responsive Carbon-Containing Titanium Dioxide Photocatalytic Nanoparticles against Anthrax
}

\author{
Der-Shan Sun ${ }^{1}$, Jyh-Hwa Kau ${ }^{2,3}$, Hsin-Hsien Huang ${ }^{3}$, Yao-Hsuan Tseng ${ }^{4}$, Wen-Shiang Wu ${ }^{1}$ \\ and Hsin-Hou Chang ${ }^{1, *}$ \\ 1 Department of Molecular Biology and Human Genetics, Tzu-Chi University, Hualien 97004, Taiwan; \\ dssun@mail.tcu.edu.tw (D.-S.S.); englishbiology@yahoo.com.tw (W.-S.W.) \\ 2 Institute of Microbiology and Immunology, National Defense Medical Center, Taipei 11490, Taiwan; \\ jhkau@ndmctsgh.edu.tw \\ 3 Institute of Preventive Medicine, National Defense Medical Center, Taipei 23742, Taiwan; \\ jhhhuang@ndmctsgh.edu.tw \\ 4 Department of Chemical Engineering, National Taiwan University of Science and Technology, \\ Taipei 10607, Taiwan; tyh@mail.ntust.edu.tw \\ * Correspondence: hhchang@mail.tcu.edu.tw; Tel.: +886-3-8565301 (ext. 2667)
}

Academic Editor: Thomas Nann

Received: 31 August 2016; Accepted: 6 December 2016; Published: 9 December 2016

\begin{abstract}
The bactericidal activity of conventional titanium dioxide $\left(\mathrm{TiO}_{2}\right)$ photocatalyst is effective only on irradiation by ultraviolet light, which restricts the applications of $\mathrm{TiO}_{2}$ for use in living environments. Recently, carbon-containing $\mathrm{TiO}_{2}$ nanoparticles $\left[\mathrm{TiO}_{2}(\mathrm{C}) \mathrm{NP}\right]$ were found to be a visible-light-responsive photocatalyst (VLRP), which displayed significantly enhanced antibacterial properties under visible light illumination. However, whether $\mathrm{TiO}_{2}(\mathrm{C}) \mathrm{NPs}$ exert antibacterial properties against Bacillus anthracis remains elusive. Here, we evaluated these VLRP NPs in the reduction of anthrax-induced pathogenesis. Bacteria-killing experiments indicated that a significantly higher proportion ( $40 \%-60 \%)$ of all tested Bacillus species, including B. subtilis, B. cereus, $B$. thuringiensis, and B. anthracis, were considerably eliminated by $\mathrm{TiO}_{2}(\mathrm{C}) \mathrm{NPs}$. Toxin inactivation analysis further suggested that the $\mathrm{TiO}_{2}(\mathrm{C}) \mathrm{NPs}$ efficiently detoxify approximately $90 \%$ of tested anthrax lethal toxin, a major virulence factor of anthrax. Notably, macrophage clearance experiments further suggested that, even under suboptimal conditions without considerable bacterial killing, the $\mathrm{TiO}_{2}(\mathrm{C}) \mathrm{NP}$-mediated photocatalysis still exhibited antibacterial properties through the reduction of bacterial resistance against macrophage killing. Our results collectively suggested that $\mathrm{TiO}_{2}(\mathrm{C}) \mathrm{NP}$ is a conceptually feasible anti-anthrax material, and the relevant technologies described herein may be useful in the development of new strategies against anthrax.
\end{abstract}

Keywords: anthrax spore; antibacterial agents; $\mathrm{TiO}_{2}$; carbon-containing $\mathrm{TiO}_{2}$; visible light responsive photocatalyst

\section{Introduction}

Anthrax is a life-threatening infectious disease that spreads through contact with spores of the Gram-positive bacterium Bacillus anthracis through skin contact (generally with infected animal products), inhalation, or ingestion [1]. Approximately 2000 to 20,000 cases occur worldwide annually [2], mostly in Africa and central and south Asia [3]. Anthrax spores have been developed as a biological weapon by several countries [4-6]. The 2001 US anthrax letter attacks further evidenced an emerging terrorist threat, leading to renewed attention to the importance of prophylaxis, prevention, and handling procedures for anthrax [7]. Agents commonly cited to inactivate anthrax spores 
include formaldehyde, hypochlorite solutions, chlorine dioxide, and radiation [8]. However, most of these agents are harmful to humans, limiting their use in public environments. Therefore, a safer disinfection technique that can exert a sustainable antimicrobial effect in human living environments is highly desirable.

Photocatalytic titanium dioxide $\left(\mathrm{TiO}_{2}\right)$ substrates have been demonstrated to eliminate organic compounds and to function as disinfectants [9]. On stimulation by ultraviolet (UV) light irradiation, the photon energy excites valance electrons and generates pairs of electrons and holes (electron vacancy in the valence band) that diffuse and become trapped on the $\mathrm{TiO}_{2}$ surfaces. These excited electrons and holes have strong reducing and oxidizing activities and react with atmospheric water and oxygen to yield reactive oxygen species (ROS) such as hydrogen peroxide $\left(\mathrm{H}_{2} \mathrm{O}_{2}\right)$, hydroxyl radicals $(\cdot \mathrm{OH})$, and superoxide anions $\left(\mathrm{O}_{2}^{-}\right)$[10], which are extremely reactive on contact with organic compounds, and have been shown to operate in concert to attack polyunsaturated phospholipids and DNA in bacteria $[9,11]$. The oxidation of bacterial cell components such as lipids and DNA might therefore result in subsequent bacterial cell death [9]. Consequently, the $\mathrm{TiO}_{2}$ photocatalytic process is a conceptually feasible disinfectant technology.

The $\mathrm{TiO}_{2}$ photocatalyst, however, is effective only on irradiation with UV light at the necessary levels, which can induce severe damage to human eyes and skin [12-15]. This greatly restricts the potential applications of the photocatalyst for use in human living environments. To solve this problem, impurity doping of $\mathrm{TiO}_{2}$ with different elements has been used, including carbon, sulfur, nitrogen, and silver, resulting in excitation wavelength shifts from the UV to visible-light [16-25]. Simultaneously, the proper amount of impurity doping of $\mathrm{TiO}_{2}$ may also reduce the recombination rates of electron and hole pairs. Previously, we reported visible-light-responsive photocatalyst (VLRP) films, which offered a complementary and possibly alternative approach for meeting this need to control the spread of anthrax [24]. However, these VLRP films must be precoated on the surfaces of particular objects, whereas photocatalytic NPs do not, and as such may have broader applications. To solve this problem, the anti-anthrax properties of VLRP carbon-containing titanium dioxide $\left[\mathrm{TiO}_{2}(\mathrm{C})\right]$ nanoparticles $\left[\mathrm{TiO}_{2}(\mathrm{C}) \mathrm{NPs}\right.$; C200 NPs] [17] were evaluated in this study. The visible-light-responsive photocatalytic activity of C200 NPs has been respectively validated by degradation of methylene blue in liquid phase, oxidation of NO in gas phase, and sterilization in these works under visible light illumination $[17,19,26-28]$. The existence of carbonaceous species on $\mathrm{TiO}_{2}$ surface was analyzed by X-ray photoelectron spectroscopy (XPS) and diffuse reflectance infrared Fourier transform spectra. The effect of carbonaceous species on physical properties was observed on UV-visible absorption spectra, photoluminescence spectroscopy, and Raman spectroscopy as shown in our previous works [26-28]. In addition, we have further demonstrated that C200 NPs exert superior Escherichia coli

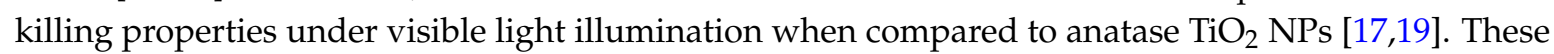
results collectively suggested that the C200 NPs exhibit a photocatalytic property under visible light illumination. However, whether C200 NPs can eliminate spore-forming bacteria such as Bacillus species has remained uncertain. Therefore, the visible-light-responsive C200 NP-mediated anti-anthrax property was evaluated. The potential applications are discussed herein.

\section{Results}

\subsection{Analyses of $\mathrm{TiO}_{2} \mathrm{NPS}$}

Detailed physical properties of UV-responsive pure $\mathrm{TiO}_{2}\left(\mathrm{TiO}_{2} ; \mathrm{UV} 100 \mathrm{TiO}_{2}\right)$ and carboncontaining $\mathrm{TiO}_{2}(\mathrm{C} 200)$ NPs have been characterized in our previous work [17,26,27]. In the present study, scanning electron microscopy and UV-Vis absorption analyses of the newly prepared C200 NPs were performed (Figure 1). We found that both $\mathrm{TiO}_{2}$ and $\mathrm{C} 200$ displayed nanoscale structures (Figure 1A,B), and that an increased content of carbon (Figure 1C) and C200 displayed considerable redshift absorbance compared with $\mathrm{TiO}_{2} \mathrm{NPs}$ (Figure 1D), indicating absorbance in the visible light range (wavelength $>380 \mathrm{~nm}$ ). The UV-Visible diffuse reflectance spectra were converted by instrument 
software to absorbance values, $F(R)$, based on the Kubelka-Munk theory. In the C200 sample, a sharp edge extending to approximately $438 \mathrm{~nm}$ and corresponding to a band gap of approximately $2.83 \mathrm{eV}$ was observed, as indicated in one of our previous reports [27].
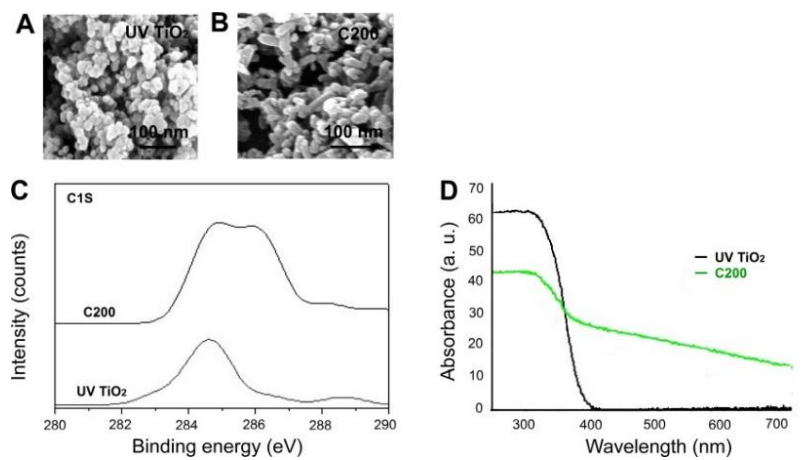

Figure 1. Scanning electron microscopy and ultraviolet-visible (UV-Vis) absorption spectrum analyses. Scanning electron microscopy (A,B), X-ray photoelectron spectroscopy (XPS) analysis for the 1s atomic

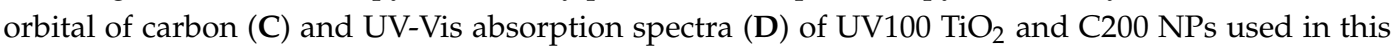
study. The C200 sample absorbed light extending into the visible $(>380 \mathrm{~nm})$ region.

\subsection{Dose-Dependent and Kinetic Analyses of Photocatalytic Inactivation of B. Subtilis}

The antibacterial properties of C200 NPs have been demonstrated [17]; however, whether C200 can also functionally eliminate spore-forming bacteria such as B. anthracis and B. subtilis remains to be further elucidated. Because B. anthracis is hazardous to humans, before analysis using B. anthracis, we employed B. subtilis as a surrogate. To obtain dose-dependent and kinetic data for B. subtilis with C200 NPs, we further analyzed the effects of illumination by visible light at various time points and at various distances $\left(5 \mathrm{~cm}, 15 \mathrm{~cm}\right.$, and with different illumination intensities of $3 \times 10^{4}$ and $5 \times 10^{2}$ lux (lumen $/ \mathrm{m}^{2}$ ); Figure 2A). The results indicated that C200 substrates can inactivate B. subtilis in half an hour when exposed to various degrees of illumination by visible light (Figure 2B). The bacteria-killing efficiency in the C200 groups was significantly higher than in the respective UV100 $\mathrm{TiO}_{2}$ groups (Figure $2 \mathrm{~A}, \mathrm{~B} ;{ }^{* *} P<0.01,{ }^{*} P<0.05$ ).
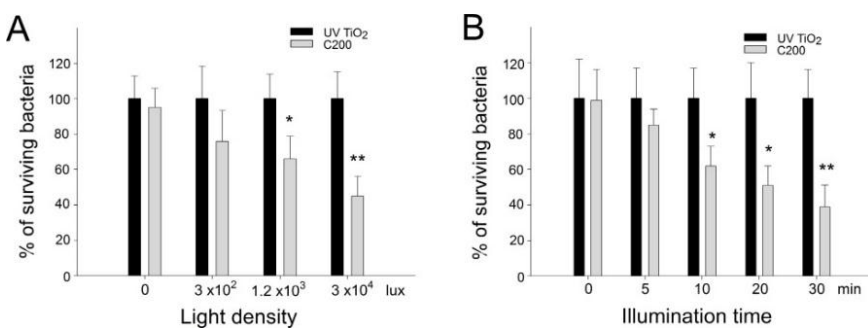

Figure 2. Dose-dependent and kinetic analyses of bactericidal activity of C200 NPs against B. subtilis. Dose-dependent (A) and kinetic (B) analyses of the bactericidal activity of $U V 100 \mathrm{TiO}_{2}$ and C200 NPs against $B$. subtilis after visible-light illumination. Illumination was carried out either at different light densities (at distances of $5 \mathrm{~cm}, 10 \mathrm{~cm}$ and $15 \mathrm{~cm}$ with respective illumination intensities of $3 \times 10^{4}$, $1.2 \times 10^{3}$ and $\left.3 \times 10^{2} \mathrm{lux}\right)$ for $30 \mathrm{~min}(\mathbf{A})$ or at a light density of $3 \times 10^{4} \mathrm{lux}\left(90 \mathrm{~mW} / \mathrm{cm}^{2}\right)$ for different periods (B). Under each illumination condition, the surviving bacteria in the $\mathrm{UV} 100 \mathrm{TiO}_{2}$ groups were normalized to $100 \%$. ${ }^{*} P<0.05$ and ${ }^{* *} P<0.01$ compared with the respective $\mathrm{UV} 100 \mathrm{TiO}_{2}$ groups. $n=6$, three experiments with two replicates.

\subsection{Antibacterial and Antispore Activities of C200 against Bacillus Species}

Photocatalyst-mediated killing was performed to determine the antibacterial and antispore effects of photocatalysis on B. cereus, B. thuringiensis, and B. anthracis. Compared with $\mathrm{UV} 100 \mathrm{TiO}_{2}$, we found that C200 NPs exhibited higher visible-light-responsive antibacterial properties to kill 
B. cereus, B. thuringiensis, and $B$. anthracis vegetative bacteria (Figure $3 \mathrm{~A},{ }^{*} P<0.05,{ }^{*} P<0.01$ ). Consistent with the antibacterial experiment, in the spore analysis, C200 also exhibited a superior visible-light-responsive antispore activity compared with the UV100 $\mathrm{TiO}_{2} \mathrm{NPs}$, although this activity was less efficient $\left(20 \%-30 \%\right.$ killing/inactivation) (Figure $\left.3 \mathrm{~B},{ }^{*} P<0.05\right)$ compared with the results obtained in vegetative bacteria experiments (Figure 3A).
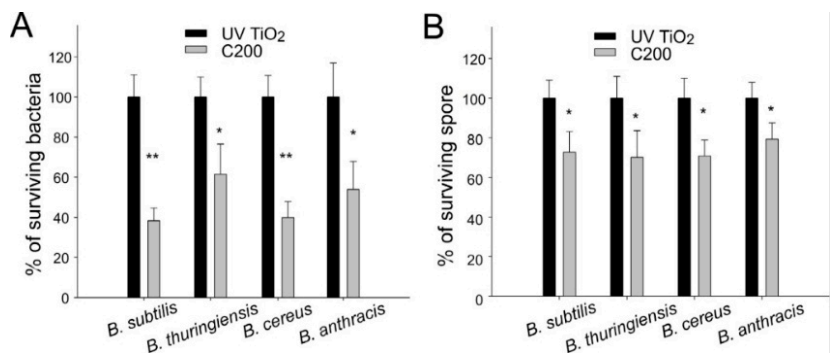

Figure 3. Antibacterial properties of C200 NPs against vegetative bacteria and spores of Bacillus species. Bacteria B. subtilis, B. thuringiensis, B. cereus, and B. anthracis were photocatalyzed using UV100 $\mathrm{TiO}_{2}$ and $\mathrm{C} 200 \mathrm{NPs}$, respectively. All vegetative bacteria (A) or spores (B) in the $\mathrm{UV} 100 \mathrm{TiO}_{2}$ groups were normalized to $100 \%$. The relative percentages of surviving pathogens in the $\mathrm{C} 200$ groups are shown. The illumination intensity was $3 \times 10^{4} \mathrm{lux}\left(90 \mathrm{~mW} / \mathrm{cm}^{2}\right)$, and the reaction time was $30 \mathrm{~min}$. ${ }^{*} P<0.05$ and ${ }^{* *} P<0.01$ compared with respective $\mathrm{UV100} \mathrm{TiO}_{2}$ groups. $n=6$, three experiments with two replicates.

\subsection{Photocatalytic Inactivation of Anthrax LT by C200 NPS}

Anthrax lethal toxin (LT), which is composed of two protein components-a protective antigen (PA; cell receptor binding) and a lethal factor (LF; metalloprotease of cellular mitogen-activated protein kinase kinase (MAPKKs, MEKs)) - is one of the major virulence factors of B. anthracis [29]. Anthrax LT can be detected in culture media and spores of B. anthracis. Treatments of LT can lead to the death of macrophage cells in vitro [30] and lead to mortality in rodents [24,31-35]. To investigate whether photocatalysis can inactivate the protein components and detoxicate the anthrax toxin, LT was subjected to visible-light-activated photocatalysis on UV100 $\mathrm{TiO}_{2}$ and C200 NPs. As expected, C200 NP-mediated photocatalysis markedly reduced the potency of LT to induce cell death of macrophage J774A.1 cells, when compared with $\mathrm{UV} 100 \mathrm{TiO}_{2}$ groups (Figure 4). These results suggested that treatment with visible-light-responsive C200-mediated photocatalysis of particular objects not only eliminates the bacteria but also reduces the toxicity of LT.

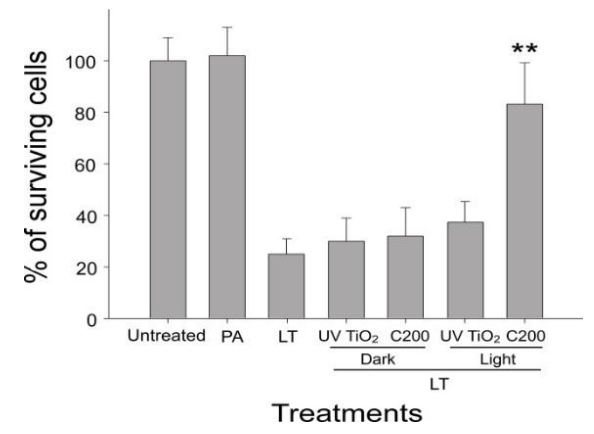

Figure 4. Visible-light-responsive C200 NP-mediated inactivation of lethal toxin (LT). Macrophage J774A. 1 cells were treated with LT with or without $\mathrm{UV} 100 \mathrm{TiO}_{2}$ and $\mathrm{C} 200$ photocatalysis for $3 \mathrm{~h}$, and surviving cells of untreated groups were adjusted to $100 \%$. Columns designated $\mathrm{UV} \mathrm{TiO}_{2}$ or $\mathrm{C} 200$ represent that LT was pretreated with photocatalysis by using UV100 $\mathrm{TiO}_{2}$ or C200 NPs, respectively, before being treated with J774A.1 cells. ${ }^{* *} P<0.01$, compared with all other groups treated with LT (with or without additional treatments). $n=6$, three experiments with two replicates. 


\subsection{In Vitro Phagocytic Clearance Analysis}

Our previous reports suggest that VLRP-mediated photocatalysis can injure bacteria [17-19,24,25] and lead to faster clearance of bacteria by phagocytes [24]. To investigate whether photocatalysis might injure the bacterium and make it more vulnerable to phagocyte-mediated killing, $B$. subtilis was used as a surrogate for B. anthracis to treat macrophage J774A.1 cells. To avoid a biased condition, we applied a subbacterial killing condition $\left(3 \times 10^{4}\right.$ for $\left.5 \mathrm{~min}\right)$, under which bacterial survival could not be considerably suppressed (Figure $2 \mathrm{~B}$ ). The analysis results revealed that $B$. subtilis in groups without antibacterial photocatalytic properties (i.e., UV100 $\mathrm{TiO}_{2}$ groups and $\mathrm{C} 200$ dark groups; Figure 2) tended to have a low reduction rate (killing by macrophages) after being engulfed by the phagocytes (Figure 5). By contrast, the levels of surviving bacteria of macrophage-engulfed B. subtilis were markedly suppressed $8 \mathrm{~h}$ after ingestion, only in C200 groups with visible-light illumination (Figure 5, C200 light group). These results suggested that the C200-mediated photocatalysis also induced damage in bacterial cells that could be repaired after plating (Figure 2B, 5 min group, not significant reduction), but resulted in a relatively vulnerable phenotype when encountering phagocytes (Figure 5, C200 light $8 \mathrm{~h}$ group). This suggested that, although the bacteria may not efficiently be killed when a subantibacterial dose of photocatalysis is applied, the bacteria that survive the photocatalysis are still more easily secured and eliminated by phagocytes in the immune system. In other words, the C200-mediated photocatalysis exhibits a protective effect against contaminated bacteria even under subbacterial killing conditions.

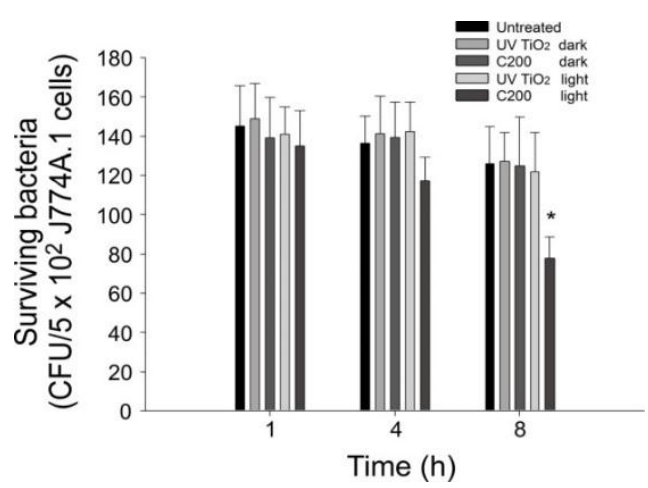

Figure 5. Surviving B. subtilis after clearance by macrophages. B. subtilis was treated with J774A.1 macrophage cells (multiplicity of infection (MOI): 0.1 bacteria/cell). Levels of surviving bacteria (colony-forming unit; CFU) harvested from macrophage cell lysate are shown. Columns designated $\mathrm{UV} \mathrm{TiO}_{2}$ and $\mathrm{C} 200$ represent that anthrax spores were pretreated with photocatalysis by using UV100 $\mathrm{TiO}_{2}$ and $\mathrm{C} 200 \mathrm{NPs}$, respectively. ${ }^{*} P<0.05$, compared with all other groups under the $8 \mathrm{~h}$ treatment condition. $n=6$, three experiments with two replicates.

\section{Discussion}

Disinfection is a vital method for controlling numerous pathogens in the sterilization of critical instruments, water treatment, food production, and hospital environments. Traditional chemical-based disinfectants, such as alcohols, aldehydes, iodine, phenols, and chlorine, have been used for centuries in environmental cleaning [18]. Among these, agents and methods such as formaldehyde, hypochlorite solutions, chlorine dioxide, and radiation have been used to inactivate anthrax spores [8]. Although these methods may be effective, they have drawbacks. Many of these disinfectants are volatile, and their byproducts can be toxic and carcinogenic to humans. The establishment and development of novel anti-anthrax strategies are necessary.

Compared with chemical disinfectants, the $\mathrm{TiO}_{2}$ photocatalyst is safe, nontoxic, and produces no hazardous byproducts [36,37]. Utilization of the excellent photocatalytic antibacterial effect of $\mathrm{TiO}_{2}$ appears to be a conceptually feasible technology for solving the aforementioned problem of 
chemical disinfectants. However, traditional antibacterial $\mathrm{TiO}_{2}$ photocatalysts are activated by UV irradiation, which is hazardous to humans $[12,13,18]$. The UV-responsive $\mathrm{TiO}_{2}$ photocatalysts are therefore unsuitable for application in indoor environments. By contrast, visible-light-activated $\mathrm{TiO}_{2}$ photocatalytic NPs exhibit at least four advantages. First, compared with UV-responsive materials, visible-light-activated $\mathrm{TiO}_{2}$ photocatalysts offer potential for use as a disinfectant in human living environments such as indoor spaces and public areas. Second, because $\mathrm{TiO}_{2}$ is a chemically stable and inert material, it can continuously exert antimicrobial action when illuminated by light. Third, the bactericidal activity can be switched on and off or modulated by controlling the light intensity. Fourth, the transportability of NPs offers greater adjustability. Because of these advantages, visible-light-activated photocatalytic NPs might be used complementarily with existing disinfection technologies against anthrax.

Emerging nanomaterials and particular NPs have been implicated as having tremendous potential applications in environmental and disinfection use [38]. We previously demonstrated that photocatalytic films can eliminate vegetative bacteria and spores of anthrax [24]. However, compared with nanostructured films, which have to be precoated at the surfaces of particular objects, NPs frequently show superior portability [39]. For example, VLRP NPs can theoretically be easier to spread into a dead corner of spore-contamination-suspected objects, houses, territorial waters, and even aerosol spaces, when compared with VLRP films. Therefore, in the present study, visible-light-responsive C200 NPs were used. For toxicity consideration, previous studies have shown that $\mathrm{TiO}_{2} \mathrm{NPs}$ are generally considered safe for skin contact or even ingestion by healthy animals [40-42]. However, inhalation of $\mathrm{TiO}_{2}$ NPs can be toxic to the lungs [42]. As a result, in a real setting, aerosol $\mathrm{TiO}_{2}$ NPs should be avoided unless the nearby persons are provided with appropriate certified masks (e.g., N95) and/or air cleaning and filtering equipment. A pioneering work demonstrated that supplements with various types of $\mathrm{NPs}$, including $\mathrm{TiO}_{2} \mathrm{NPs}$, may reduce the growth of Escherichia coli and B. anthracis in bacterial culture [43]; however, it showed that the growth retardation effect was due to the presence of excessive NPs in the culture medium rather than bacterial killing. In addition, the photocatalytic effect of $\mathrm{TiO}_{2} \mathrm{NPs}$ on $\mathrm{B}$. anthracis has not yet been reported. Therefore, to determine a more efficient way to eliminate the contaminated pathogenic bacteria, relevant verifications that involve using photocatalytic NPs are necessary.

Carbon-containing titanium dioxide C200 NPs exhibit considerably superior photocatalytic properties under visible-light illumination compared with UV100 $\mathrm{TiO}_{2}$ NPs [17,19,24,26-28]. However, whether C200 NPs can eliminate spore-forming bacteria such as Bacillus species has remained elusive. Therefore, in the present study, we demonstrated that visible-light-responsive C200 NP-mediated photocatalysis can eliminate considerable levels of both vegetative bacteria and spores of Bacillus species, including B. subtilis, B. cereus, B. thuringiensis, and B. anthracis. The analysis data suggested that C200 NPs are useful for eliminating contamination of these spore-forming bacteria. Notably, in agreement with our previous findings [24], our data suggest that C200-mediated photocatalysis somehow injures the bacteria even under suboptimal antibacterial conditions, thus leading to faster clearance of the photocatalyzed bacteria by phagocytes (Figure 5). This suggests that C200 can still exert anti-anthrax properties even at a subantibacterial level.

\section{Materials and Methods}

\subsection{Preparation of Photocatalysts}

Visible-light-responsive carbon-containing mixed phase $\mathrm{TiO}_{2}$ nanoparticles $\left[\mathrm{TiO}_{2}(\mathrm{C}) \mathrm{NPs}\right.$; C200 NPs] were prepared using a modified sol-gel method as previously described $[17,26,27]$. A measured quantity of tetrabutyl orthotitanate $(50 \mathrm{mmol})$ was slowly introduced into $90 \mathrm{~mL}$ of anhydrate ethanol and $20 \mathrm{~mL}$ of deionized (DI) water in a $250 \mathrm{~mL}$ flask. After complete dissolution, $4 \mathrm{~mL}$ of nitric acid was added to catalyze the hydrolysis and condensation reactions. The mixed solution was uniformly agitated at $500 \mathrm{rpm}$ for $3 \mathrm{~h}$, producing a precipitate of titanium hydroxide. After drying 
at $110{ }^{\circ} \mathrm{C}$, the dried powder was calcined in air at $20{ }^{\circ} \mathrm{C}$ for $5 \mathrm{~h}$ and designated as $\mathrm{C} 200[17,24,26,27]$. Details of preparing the production of $\mathrm{C} 200$, including structural properties and the sizes of primary particles, were reported in our earlier work [27]. The surface of C200 was found to contain unique anatase/rutile mixed crystalline phases that exhibit strong visible-light absorption and photocatalytic effects $[22,23]$. The carbonaceous species on $\mathrm{TiO}_{2}(\mathrm{C}) \mathrm{NPs}$ exist in an amorphous form, as observed in Raman spectra [26-28]. One commercially available $\mathrm{TiO}_{2} \mathrm{NP}$ (UV100, Sachtleben, Germany) that can exert photocatalytic properties only when illuminated by UV light was used for comparison. Because C200 samples often aggregate into larger clusters because of surface charges, in Van der Waals interactions, we dispersed the aggregates by using sonication (Transsonic Digital TP680DH, Elma Schmidbauer, Singen, Germany) before the bacteria-killing or bacteria-photocatalyst interaction experiments. The UV-Vis absorption spectra were recorded on a Hitachi $3300 \mathrm{H}$ spectrophotometer (Hitachi Taiwan, Taipei, Taiwan) [24,44]. Particle size and morphology were determined using a transmission electron microscope (Philips Tecnai F20 G2 FEI-TEM, Philips Taiwan, Taipei, Taiwan) and a scanning electron microscope (JEM-3010, JEOL, Tokyo, Japan) [17,21]. Material compositions were determined using X-ray photoelectron spectroscopy (Perkin Elmer SSI-M probe XPS system and S4800, Waltham, MA, USA).

\subsection{Bacterial Strains and Culture}

Bacterial culture and maintenance were conducted according to previously described methods [24]. B. anthracis (ATCC 14186) containing both $\mathrm{pXO1}$ and $\mathrm{pXO} 2$ plasmids to express functional LT and edema toxin (ET) was grown on blood agar plates (BAPs) and maintained in brain-heart infusion broth (BHIB) (Sigma-Aldrich, St. Louis, MO, USA) using previously described methods [17,24,30-34,45-47]. B. cereus (ATCC 13061) and B. thuringiensis (ATCC 35646) were maintained and cultured in BAPs or BHIB at $30^{\circ} \mathrm{C}$, and B. subtilis (ATCC 39090) was maintained and cultured in trypticase soy agar or broth (Sigma-Aldrich, St. Louis, MO, USA) at $37^{\circ} \mathrm{C}[24,48]$. Bacterial strains were stored in a 50\% culture medium and $50 \%$ glycerol solution at $-80{ }^{\circ} \mathrm{C}$ before use. To reactivate bacteria from frozen stock, $25 \mu \mathrm{L}$ of bacterial stock solution was transferred to a test tube containing $5 \mathrm{~mL}$ of a freshly prepared culture medium and then incubated at $30^{\circ} \mathrm{C}$ or $37^{\circ} \mathrm{C}$ under agitation overnight $(16-18 \mathrm{~h})$. Spores of B. anthracis were prepared as previously described $[24,49,50]$. Overnight BHIB cultures of B. anthracis were diluted to approximately $10^{7}$ colony-forming units (CFU)/mL in phosphate-buffered saline, and $0.1-\mathrm{mL}$ aliquots were inoculated onto blood agar plates. The agar plates were incubated at $25-37^{\circ} \mathrm{C}$ until $90 \%-99 \%$ phase-bright spores were observed using phase-contrast light microscopy. Spores were harvested and washed with cold sterile DI water as previously described [49] and stored in the freezer at $-20^{\circ} \mathrm{C}$ for up to $1 \mathrm{~mol}$. The quality of spores was determined by two complementary criteria previously established for validating the presence of dormant spores [50]. The criteria consisted of evaluating (i) the absence of vegetative cells (rods) determined through microscopic examination as described, and (ii) the survival of spores in hydrochloric acid $(2.5 \mathrm{~N})$. Spore preparations of B. subtilis, $B$. cereus, and B. thuringiensis were conducted following the same protocol.

\subsection{Photocatalytic Reaction and Detection of Viable Bacteria}

In this study, bacterial concentrations were either determined using the standard plating method or inferred from optical density readings at $600 \mathrm{~nm}$ (OD600). For each Bacillus species, a factor for converting the OD600 values of the bacterial culture to concentration $(\mathrm{CFU} / \mathrm{mL})$ was calculated as follows. A fresh bacterial culture was diluted by factors of $10^{-1}$ to $10^{-7}$, and the OD600 of these dilutions was measured. The bacterial concentrations of these dilutions were determined using the standard plating method. To determine the bactericidal effects of the $\mathrm{TiO}_{2}$-related substrates, $200 \mu \mathrm{L}$ of bacterial overnight culture was transferred into $5 \mathrm{~mL}$ of a culture medium and incubated at $37^{\circ} \mathrm{C}$ until an OD600 of 0.3-0.6 (log phase) was reached. The bacterial concentrations were calculated using the previously determined conversion factor for the bacteria, and the cultures were diluted to $1 \times 10^{5} \mathrm{CFU} / \mathrm{mL}$ with the culture medium. The bacterial cultures $\left(2.5 \times 10^{4} \mathrm{CFU}\right)$ were mixed 
with the $\mathrm{TiO}_{2}$ or C200 NPs $(200 \mu \mathrm{g} / \mathrm{mL}$ in $150 \mu \mathrm{L}$ of normal saline) using a $200 \mu \mathrm{L}$ pipetman and placed onto a 24-well cell culture dish. Photocatalytic reactions were carried out using an incandescent lamp (Classictone incandescent lamp, 60 W, Philips Taiwan, Taipei, Taiwan). A light meter (model LX-102, Lutron Electronic Enterprises, Taipei, Taiwan) was used to record the illumination density. In the dose-dependent experiments, illumination was carried out for 5 min at distances of 5,10 and $15 \mathrm{~cm}$ from the lamp, corresponding to illumination densities of $3 \times 10^{4}, 1.2 \times 10^{3}$ and $3 \times 10^{2}$ lux (lumen $/ \mathrm{m}^{2}$ ) (equivalent to 90,30 and $10 \mathrm{~mW} / \mathrm{cm}^{2}$ ), respectively. In the kinetic analysis experiments, illumination was carried out for 1,5,10,20 and $30 \mathrm{~min}$ at a distance of $5 \mathrm{~cm}$, corresponding to an illumination density of $3 \times 10^{4} \mathrm{lux}\left(90 \mathrm{~mW} / \mathrm{cm}^{2}\right)$. Unless specified, illumination was carried out in a $4{ }^{\circ} \mathrm{C}$ cold room to prevent overheating of the photocatalyst-containing solution. After illumination, the levels of surviving bacteria were determined using a standard plating method immediately after bacterial collection. In the spore experiments, $1 \times 10^{4} \mathrm{CFU}\left(1 \times 10^{5} \mathrm{CFU} / \mathrm{mL}\right.$ in $\left.100 \mu \mathrm{L}\right)$ was used, and the procedures followed the same protocols as those in the live bacteria experiments.

\subsection{Cytotoxicity Analysis}

Cytotoxicity of anthrax LT was measured following previously described methods [30,45]. Anthrax LT is composed of two protein components, a PA (cell receptor-binding) and an LF (metalloprotease). The PA and LF were purified from B. anthracis (ATCC 14186) culture supernatants, as previously described [24,30-34,45,47]. The culture supernatants were filter-sterilized by being passed through a $0.22-\mathrm{mm}$ filter (Millipore, Bedford, MA, USA) and concentrated using the Minitan Ultrafiltration System (Millipore, Bedford, MA, USA). Protease inhibitor phenylmethylsulfonyl fluoride $0.1 \mathrm{mM}$ (Sigma-Aldrich, St. Louis, MO, USA) [51,52] was added to prevent toxin degradation. Ammonium sulfate was added to $75 \%$ to precipitate the protein; and the protein was collected and suspended in $20 \mathrm{mM}$ tris(hydroxymethyl)aminomethane $\mathrm{HCl}$ (Tris- $\mathrm{HCl}$ ) pH 8.0, and extensively dialyzed against the same buffer. The purification was further performed using fast protein liquid chromatography Mono Q anion exchange (Pharmacia, Piscataway, NJ, USA) with a $20 \mathrm{mM}$ Tris- $\mathrm{HCl}$ pH 8.0 buffer and linear $0-400 \mathrm{mM} \mathrm{NaCl}$ gradient elution over $40 \mathrm{~min}$. The PA was eluted at 130-140 mM NaCl, and the LF was eluted at 250-270 mM NaCl. Lipopolysaccharide (LPS) contamination was monitored using a Limulus Amoebocyte Lysate QCL-1000 kit (Lonza, Walkersville, MD, USA) [31,35,53]. Batches of purified LT with an LPS contamination level of less than $1 \mathrm{EU} / \mathrm{mg}$ of LT were used [31]. The LT solution was mixed with the $\mathrm{TiO}_{2}$ or C200 nanoparticles $(200 \mu \mathrm{g} / \mathrm{mL}$ in $150 \mu \mathrm{L}$ of normal saline) by using a $200 \mu \mathrm{L}$ pipetman and placed onto a 24 -well cell culture dish. After inactivation in visible-light illumination for $30 \mathrm{~min}\left(3 \times 10^{4} \mathrm{lux} ; 90 \mathrm{~mW} / \mathrm{cm}^{2}\right)$, the LT (LF:PA = 1:5) was ready for use. Cytotoxic doses of LT (10 mg/L) [30], with or without pretreatment of photocatalytic inactivation using pure $\mathrm{TiO}_{2}$ and C200 NPs, was used to treat mouse macrophage J774A.1 cells. Three hours after the LT treatments, the cell viability of J774A.1 cells was measured using a WST-1 kit (Roche, Mannheim, Germany) [30,53,54], following manufacturer instructions.

\subsection{Phagocytosis Analysis}

B. subtilis was dissolved in normal saline $\left(100 \mu \mathrm{L}, 1 \times 10^{5} \mathrm{CFU} / \mathrm{mL}\right)$ and then incubated with $\mathrm{TiO}_{2}$ and C200 NPs. The bacterial cultures $\left(2.5 \times 10^{4} \mathrm{CFU}\right)$ were mixed with $\mathrm{TiO}_{2}$ or C200 NPs (200 $\mu \mathrm{g} / \mathrm{mL}$ in $150 \mu \mathrm{L}$ of normal saline) using a $200 \mu \mathrm{L}$ pipetman and placed onto a 24 -well cell culture dish. The bacterium-photocatalyst mixtures were then illuminated with visible light (Classictone incandescent lamp, $60 \mathrm{~W}$, Philips; $90 \mathrm{~mW} / \mathrm{cm}^{2}$; lamp target distance $10 \mathrm{~cm}$ ) for $30 \mathrm{~min}$ in 24-well plates. After illumination, the bacteria-containing solutions $(85 \mu \mathrm{L})$ were recovered from the 24 -well plates. The bacterial solution was then added into one well of a six-well cell culture dish containing confluent murine macrophage J774A. 1 cells $\left(1 \times 10^{6}\right.$ cells/well; MOI: 0.1 bacteria/cell). After phagocytosis was carried out for $1 \mathrm{~h}$, the culture medium was removed, and $200 \mu \mathrm{L}$ of a cell lysis buffer $(100 \mathrm{mM}$ Tris- $\mathrm{HCl}$ [pH 7.4], $10 \mathrm{mM} \mathrm{MgCl}_{2}, 100 \mathrm{mM} \mathrm{NaCl}, 0.2 \%$ sucrose, $0.5 \%$ Triton X-100) modified from that described in previous literature $[55,56]$ was then added to release the cell-engulfed or cell-bound bacteria. 
A serum-free and antibiotic-free cell culture medium (Dulbecco's modified Eagle's medium) was used in this analysis.

\subsection{Statistical Analyses}

The means, standard deviations, and statistics for the quantifiable data were calculated using Microsoft Office Excel 2003 (Microsoft, Redmond, WA, USA), SigmaPlot 10 (Systat Software, San Jose, CA, USA), and SPSS Statistics for Windows, Version 19.0 (IBM, Armonk, NY, USA). Significance of the data was examined using one-way ANOVA followed by the post hoc Bonferroni-corrected test. The probability of type 1 error $\alpha=0.05$ was recognized to be the threshold of statistical significance.

\section{Conclusions}

In the present study, we demonstrated that C200 NPs are conceptually feasible nanomaterials for eliminating the vegetative cells and spores of B. anthracis. In particular, C200-mediated photocatalysis exhibits a protective effect against the bacteria, even under suboptimal conditions. Our results collectively suggest that C200 NPs and the extended concepts and technologies described in this report are useful for the development of new strategies against anthrax.

Acknowledgments: This work was supported by Ministry of Science and Technology of Taiwan R.O.C. under Grant No. 95-2314-B-320-009-MY3 and 102-2221-E-259-005-MY3, and Ministry of Economic Affairs of Taiwan R.O.C. under Grant No. 98-EC-17-A-19-S2-0111.

Author Contributions: Hsin-Hou Chang and Der-Shan Sun conceived and designed the experiments; Der-Shan Sun, Jyh-Hwa Kau, Wen-Shiang $\mathrm{Wu}$ and Hsin-Hsien Huang performed the experiments; Hsin-Hou Chang and Jyh-Hwa Kau analyzed the data; Yao-Hsuan Tseng and Hsin-Hsien Huang contributed materials; Hsin-Hou Chang wrote the paper.

Conflicts of Interest: The authors declare no conflict of interest.

\section{Abbreviations}

The following abbreviations are used in this manuscript:

$\begin{array}{ll}\mathrm{TiO}_{2} & \text { titanium dioxide } \\ \mathrm{TiO}_{2}(\mathrm{C}) & \text { carbon-containing } \mathrm{TiO}_{2} \\ \text { VLRP } & \text { visible-light-responsive photocatalyst } \\ \mathrm{NPs} & \text { nanoparticles } \\ \mathrm{UV} & \text { ultraviolet } \\ \mathrm{ROS} & \text { reactive oxygen species } \\ \mathrm{H}_{2} \mathrm{O}_{2} & \text { hydrogen peroxide } \\ \bullet \mathrm{OH} & \text { hydroxyl radicals } \\ \mathrm{O}_{2}^{-} & \text {superoxide anions } \\ \text { LT } & \text { anthrax lethal toxin } \\ \mathrm{PA} & \text { anthrax protective antigen } \\ \text { LF } & \text { anthrax lethal factor } \\ \text { ET } & \text { anthrax edema toxin } \\ \text { MOI } & \text { multiplicity of infection } \\ \text { CFU } & \text { colony-forming units } \\ \text { LPS } & \text { lipopolysaccharide }\end{array}$

\section{References}

1. World Health Organization. Anthrax in humans and animals. In Anthrax in Humans and Animals, 4th ed.; World Health Organization: Geneva, Switzerland, 2008.

2. Goel, A.K. Anthrax: A disease of biowarfare and public health importance. World J. Clin. Cases 2015, 3, $20-33$. [CrossRef] [PubMed]

3. Doganay, M.; Demiraslan, H. Human anthrax as a re-emerging disease. Recent Pat. Antiinfect. Drug Discov. 2015, 10, 10-29. [CrossRef] [PubMed]

4. Frischknecht, F. The history of biological warfare. Human experimentation, modern nightmares and lone madmen in the twentieth century. EMBO Rep. 2003, 4, S47-S52. [CrossRef] [PubMed]

5. Riedel, S. Biological warfare and bioterrorism: A historical review. Proceedings 2004, 17, 400-406. 
6. Inglesby, T.V.; O’Toole, T.; Henderson, D.A.; Bartlett, J.G.; Ascher, M.S.; Eitzen, E.; Friedlander, A.M.; Gerberding, J.; Hauer, J.; Hughes, J.; et al. Anthrax as a biological weapon, 2002: Updated recommendations for management. JAMA 2002, 287, 2236-2252. [CrossRef] [PubMed]

7. Hamburg, M.A. Bioterrorism: Responding to an emerging threat. Trends Biotechnol. 2002, 20, $296-298$. [CrossRef]

8. Spotts Whitney, E.A.; Beatty, M.E.; Taylor, T.H., Jr.; Weyant, R.; Sobel, J.; Arduino, M.J.; Ashford, D.A. Inactivation of bacillus anthracis spores. Emerg. Infect. Dis. 2003, 9, 623-627. [CrossRef] [PubMed]

9. Maness, P.C.; Smolinski, S.; Blake, D.M.; Huang, Z.; Wolfrum, E.J.; Jacoby, W.A. Bactericidal activity of photocatalytic $\mathrm{TiO}_{2}$ reaction: Toward an understanding of its killing mechanism. Appl. Environ. Microbiol. 1999, 65, 4094-4098. [PubMed]

10. Fujishima, A.; Honda, K. Electrochemical photolysis of water at a semiconductor electrode. Nature 1972, 238, 37-38. [CrossRef] [PubMed]

11. Hirakawa, K.; Mori, M.; Yoshida, M.; Oikawa, S.; Kawanishi, S. Photo-irradiated titanium dioxide catalyzes site specific DNA damage via generation of hydrogen peroxide. Free Radic. Res. 2004, 38, 439-447. [CrossRef] [PubMed]

12. Hearing, V.J. Biogenesis of pigment granules: A sensitive way to regulate melanocyte function. J. Dermatol. Sci. 2005, 37, 3-14. [CrossRef] [PubMed]

13. Slominski, A.; Pawelek, J. Animals under the sun: Effects of ultraviolet radiation on mammalian skin. Clin. Dermatol. 1998, 16, 503-515. [CrossRef]

14. Roberts, J.E. Ocular phototoxicity. J. Photochem. Photobiol. B 2001, 64, 136-143. [CrossRef]

15. Wu, M.S.; Sun, D.S.; Lin, Y.C.; Cheng, C.L.; Hung, S.C.; Chen, P.K.; Yang, J.H.; Chang, H.H. Nanodiamonds protect skin from ultraviolet b-induced damage in mice. J. Nanobiotech. 2015, 13, 35. [CrossRef] [PubMed]

16. Chang, W.K.; Sun, D.S.; Chan, H.; Huang, P.T.; Wu, W.S.; Lin, C.H.; Tseng, Y.H.; Cheng, Y.H.; Tseng, C.C.; Chang, H.H. Visible light responsive core-shell structured $\mathrm{In}_{2} \mathrm{O}_{3} @ \mathrm{CaIn} 2 \mathrm{O}_{4}$ photocatalyst with superior bactericidal property and biocompatibility. Nanomedicine 2012, 8, 609-617. [CrossRef] [PubMed]

17. Cheng, C.L.; Sun, D.S.; Chu, W.C.; Tseng, Y.H.; Ho, H.C.; Wang, J.B.; Chung, P.H.; Chen, J.H.; Tsai, P.J.; Lin, N.T.; et al. The effects of the bacterial interaction with visible-light responsive titania photocatalyst on the bactericidal performance. J. Biomed. Sci. 2009, 16, 7. [CrossRef] [PubMed]

18. Liou, J.W.; Chang, H.H. Bactericidal effects and mechanisms of visible light-responsive titanium dioxide photocatalysts on pathogenic bacteria. Archi. Immunol. Ther. Ex. 2012, 60, 267-275. [CrossRef] [PubMed]

19. Liou, J.W.; Gu, M.H.; Chen, Y.K.; Chen, W.Y.; Chen, Y.C.; Tseng, Y.H.; Hung, Y.J.; Chang, H.H. Visible light responsive photocatalyst induces progressive and apical-terminus preferential damages on Escherichia coli surfaces. PLoS ONE 2011, 6, e19982. [CrossRef] [PubMed]

20. Tseng, Y.H.; Sun, D.S.; Wu, W.S.; Chan, H.; Syue, M.S.; Ho, H.C.; Chang, H.H. Antibacterial performance of nanoscaled visible-light responsive platinum-containing titania photocatalyst in vitro and in vivo. Biochim. Biophys. Acta 2013, 1830, 3787-3795. [CrossRef] [PubMed]

21. Wong, M.S.; Chen, C.W.; Hsieh, C.C.; Hung, S.C.; Sun, D.S.; Chang, H.H. Antibacterial property of Ag nanoparticle-impregnated N-doped titania films under visible light. Sci. Rep. 2015, 5, 11978. [CrossRef] [PubMed]

22. Wong, M.S.; Chu, W.C.; Sun, D.S.; Huang, H.S.; Chen, J.H.; Tsai, P.J.; Lin, N.T.; Yu, M.S.; Hsu, S.F.; Wang, S.L.; et al. Visible-light-induced bactericidal activity of a nitrogen-doped titanium photocatalyst against human pathogens. Appl. Environ. Microbiol. 2006, 72, 6111-6116. [CrossRef] [PubMed]

23. Wong, M.S.; Sun, D.S.; Chang, H.H. Bactericidal performance of visible-light responsive titania photocatalyst with silver nanostructures. PLoS ONE 2010, 5, e10394. [CrossRef] [PubMed]

24. Kau, J.H.; Sun, D.S.; Huang, H.H.; Wong, M.S.; Lin, H.C.; Chang, H.H. Role of visible light-activated photocatalyst on the reduction of anthrax spore-induced mortality in mice. PLoS ONE 2009, 4, e4167. [CrossRef] [PubMed]

25. Chen, Y.L.; Chen, Y.S.; Chan, H.; Tseng, Y.H.; Yang, S.R.; Tsai, H.Y.; Liu, H.Y.; Sun, D.S.; Chang, H.H. The use of nanoscale visible light-responsive photocatalyst $\mathrm{TiO}_{2}-\mathrm{Pt}$ for the elimination of soil-borne pathogens. PLOS ONE 2012, 7, e31212.

26. Tseng, Y.H.; Kuo, C.S.; Huang, C.H.; Li, Y.Y.; Chou, P.W.; Cheng, C.L.; Wong, M.S. Visible-light-responsive nano- $\mathrm{TiO}_{2}$ with mixed crystal lattice and its photocatalytic activity. Nanotechnology 2006, 17, 2490-2497. [CrossRef] [PubMed] 
27. Chou, P.W.; Treschev, S.; Chung, P.H.; Cheng, C.L.; Tseng, Y.H.; Chen, Y.J.; Wong, M.S. Observation of carbon-containing nanostructured mixed titania phases for visible-light photocatalysts. Appl. Phys. Lett. 2006, 89, 131919. [CrossRef]

28. Treschev, S.; Chou, P.W.; Tseng, Y.H.; Wang, J.B.; Perevedentseva, E.V.; Cheng, C.L. Photoactivities of the visible-light-activated mixed-phase carbon-containing titanium dioxide: The effect of carbon incorporation. Appl. Catal. B 2007, 79, 8-16. [CrossRef]

29. Friebe, S.; van der Goot, F.G.; Burgi, J. The ins and outs of anthrax toxin. Toxins 2016, 8, 69. [CrossRef] [PubMed]

30. Kau, J.H.; Sun, D.S.; Huang, H.S.; Lien, T.S.; Huang, H.H.; Lin, H.C.; Chang, H.H. Sublethal doses of anthrax lethal toxin on the suppression of macrophage phagocytosis. PLoS ONE 2010, 5, e14289. [CrossRef] [PubMed]

31. Sun, D.S.; Lee, P.C.; Kau, J.H.; Shih, Y.L.; Huang, H.H.; Li, C.R.; Lee, C.C.; Wu, Y.P.; Chen, K.C.; Chang, H.H. Acquired coagulant factor VIII deficiency induced by bacillus anthracis lethal toxin in mice. Virulence 2015, 6, 466-475. [CrossRef] [PubMed]

32. Chen, P.K.; Chang, H.H.; Lin, G.L.; Wang, T.P.; Lai, Y.L.; Lin, T.K.; Hsieh, M.C.; Kau, J.H.; Huang, H.H.; Hsu, H.L.; et al. Suppressive effects of anthrax lethal toxin on megakaryopoiesis. PLoS ONE 2013, 8, e59512. [CrossRef] [PubMed]

33. Chang, H.H.; Chiang, Y.W.; Lin, T.K.; Lin, G.L.; Lin, Y.Y.; Kau, J.H.; Huang, H.H.; Hsu, H.L.; Wang, J.H.; Sun, D.S. Erythrocytic mobilization enhanced by the granulocyte colony-stimulating factor is associated with reduced anthrax-lethal-toxin-induced mortality in mice. PLoS ONE 2014, 9, e111149. [CrossRef] [PubMed]

34. Chang, H.H.; Wang, T.P.; Chen, P.K.; Lin, Y.Y.; Liao, C.H.; Lin, T.K.; Chiang, Y.W.; Lin, W.B.; Chiang, C.Y.; $\mathrm{Kau}$, J.H.; et al. Erythropoiesis suppression is associated with anthrax lethal toxin-mediated pathogenic progression. PLoS ONE 2013, 8, e71718. [CrossRef] [PubMed]

35. Kau, J.H.; Shih, Y.L.; Lien, T.S.; Lee, C.C.; Huang, H.H.; Lin, H.C.; Sun, D.S.; Chang, H.H. Activated protein c ameliorates bacillus anthracis lethal toxin-induced lethal pathogenesis in rats. J. Biomed. Sci. 2012, $19,98$. [CrossRef] [PubMed]

36. Gamage, J.; Zhang, Z. Applications of photocatalytic disinfection. Intl. J. Photoenergy 2010, 2010, 764870. [CrossRef]

37. Fujishima, A. Titanium dioxide photocatalysis. J. Photochem. Photobiol. C 2000, 1, 1-21.

38. Ibrahim, R.K.; Hayyan, M.; AlSaadi, M.A.; Hayyan, A.; Ibrahim, S. Environmental application of nanotechnology: Air, soil, and water. Environ. Sci. Pollut. Res. Int. 2016, 23, 13754-13788. [CrossRef] [PubMed]

39. Application of Nanotechnology: Enviroment. Available online: http://www.nanocap.eu/Flex/Site/ Download2e90.pdf?ID=2258 (accessed on 8 December 2016).

40. Bernard, B.K.; Osheroff, M.R.; Hofmann, A.; Mennear, J.H. Toxicology and carcinogenesis studies of dietary titanium dioxide-coated mica in male and female fischer 344 rats. J. Toxicol. Environ. Health 1990, 29, 417-429. [CrossRef] [PubMed]

41. Valant, J.; Drobne, D.; Novak, S. Effect of ingested titanium dioxide nanoparticles on the digestive gland cell membrane of terrestrial isopods. Chemosphere 2012, 87, 19-25. [CrossRef] [PubMed]

42. Shi, H.; Magaye, R.; Castranova, V.; Zhao, J. Titanium dioxide nanoparticles: A review of current toxicological data. Part. Fibre Toxicol. 2013, 10, 15. [CrossRef] [PubMed]

43. Sloan, M.; Farnsworth, S. Testing and Eevaluation of Nanoparticle Efficacy on E. Coli, and Bacillus Anthracis Spores. NSTI-Nanotech 2006, 1, 595-598.

44. Lin, Y.C.; Tsai, L.W.; Perevedentseva, E.; Chang, H.H.; Lin, C.H.; Sun, D.S.; Lugovtsov, A.E.; Priezzhev, A.; Mona, J.; Cheng, C.L. The influence of nanodiamond on the oxygenation states and micro rheological properties of human red blood cells in vitro. J. Biomed. Opt. 2012, 17, 101512. [CrossRef] [PubMed]

45. Chang, H.H.; Tsai, M.F.; Chung, C.P.; Chen, P.K.; Hu, H.I.; Kau, J.H.; Huang, H.H.; Lin, H.C.; Sun, D.S. Single-step purification of recombinant anthrax lethal factor from periplasm of Escherichia coli. J. Biotechnol. 2006, 277-285. [CrossRef] [PubMed]

46. Kau, J.H.; Lin, C.G.; Huang, H.H.; Hsu, H.L.; Chen, K.C.; Wu, Y.P.; Lin, H.C. Calyculin a sensitive protein phosphatase is required for bacillus anthracis lethal toxin induced cytotoxicity. Curr. Microbiol. 2002, 44, 106-111. [CrossRef] [PubMed] 
47. Kau, J.H.; Sun, D.S.; Tsai, W.J.; Shyu, H.F.; Huang, H.H.; Lin, H.C.; Chang, H.H. Antiplatelet activities of anthrax lethal toxin are associated with suppressed p42/44 and p38 mitogen-activated protein kinase pathways in the platelets. J. Infect. Dis. 2005, 192, 1465-1474. [CrossRef] [PubMed]

48. Kort, R.; O’Brien, A.C.; van Stokkum, I.H.; Oomes, S.J.; Crielaard, W.; Hellingwerf, K.J.; Brul, S. Assessment of heat resistance of bacterial spores from food product isolates by fluorescence monitoring of dipicolinic acid release. Appl. Environ. Microbiol. 2005, 71, 3556-3564. [CrossRef] [PubMed]

49. Carrera, M.; Zandomeni, R.O.; Fitzgibbon, J.; Sagripanti, J.L. Difference between the spore sizes of bacillus anthracis and other bacillus species. J. Appl. Microbiol. 2007, 102, 303-312. [CrossRef] [PubMed]

50. Sagripanti, J.L.; Bonifacino, A. Comparative sporicidal effects of liquid chemical agents. Appl. Environ. Microbiol. 1996, 62, 545-551. [PubMed]

51. Chang, H.H.; Chen, P.K.; Lin, G.L.; Wang, C.J.; Liao, C.H.; Hsiao, Y.C.; Dong, J.H.; Sun, D.S. Cell adhesion as a novel approach to determining the cellular binding motif on the severe acute respiratory syndrome coronavirus spike protein. J. Virol. Methods 2014, 201, 1-6. [CrossRef] [PubMed]

52. Chang, J.C.; Chang, H.H.; Lin, C.T.; Lo, S.J. The integrin $\alpha 6 \beta 1$ modulation of PI3K and Cdc42 activities induces dynamic filopodium formation in human platelets. J. Biomed. Sci. 2005, 12, 881-898. [CrossRef] [PubMed]

53. Chang, H.H.; Shyu, H.F.; Wang, Y.M.; Sun, D.S.; Shyu, R.H.; Tang, S.S.; Huang, Y.S. Facilitation of cell adhesion by immobilized dengue viral nonstructural protein $1\left(\mathrm{NS}_{1}\right)$ : Arginine-glycine-aspartic acid structural mimicry within the dengue viral $\mathrm{NS}_{1}$ antigen. J. Infect. Dis. 2002, 186, 743-751. [CrossRef] [PubMed]

54. Sun, D.S.; Chang, Y.C.; Lien, T.S.; King, C.C.; Shih, Y.L.; Huang, H.S.; Wang, T.Y.; Li, C.R.; Lee, C.C.; Hsu, P.N.; et al. Endothelial cell sensitization by death receptor fractions of an anti-dengue nonstructural protein 1 antibody induced plasma leakage, coagulopathy, and mortality in mice. J. Immunol. 2015, 195, 2743-2753. [CrossRef] [PubMed]

55. Chang, H.H.; Shih, K.N.; Lo, S.J. Receptor-mediated endocytosis as a selection force to enrich bacteria expressing rhodostomin on their surface. J. Biomed. Sci. 2000, 7, 42-50. [CrossRef] [PubMed]

56. Leahy, M.B.; Dessens, J.T.; Nuttall, P.A. Striking conformational similarities between the transcription promoters of thogoto and influenza a viruses: Evidence for intrastrand base pairing in the $5^{\prime}$ promoter arm. J. Virol. 1997, 71, 8352-8356. [PubMed]

(C) 2016 by the authors; licensee MDPI, Basel, Switzerland. This article is an open access article distributed under the terms and conditions of the Creative Commons Attribution (CC-BY) license (http://creativecommons.org/licenses/by/4.0/). 